\title{
HUBUNGAN TINGGI BADAN DENGAN PANJANG TANGAN PADA MAHASISWA FAKULTAS KEDOKTERAN UNSRAT ANGKATAN 2013
}

\author{
${ }^{1}$ Christanti Sambeka \\ ${ }^{2}$ George N. Tanudjaja \\ ${ }^{2}$ Taufiq F. Pasiak
}

\author{
${ }^{1}$ Kandidat Skripsi Fakultas Kedokteran Universitas Sam Ratulangi Manado \\ ${ }^{2}$ Bagian Anatomi-Histologi Fakultas Kedokteran Universitas Sam Ratulangi Manado \\ Email: csambeka_11_007@yahoo.com
}

\begin{abstract}
Identification is important to the victims who have died, because identification is needed to know the person's identity. Body height can be determined using bones measurement, including metacarpal and phalanx. The purpose of this study is to find out the correlation of body height with hand length in the medical student of Sam Ratulangi University class of 2013. This study is an analytic descriptive study with design of crosssectional study, and total participants of 72 students comprise of 36 male and 36 female. The samples of this study were chosen using the simple random sampling technique and were analyzed with the Pearson correlation analysis and also with the simple linear regression. The result showed a strong correlation between body heights and hand length with the value of ' $r$ ' in total was 0.855 in the whole subjects and 0.753 in male samples whereas in the female samples the value was 0.603 . Based on the result of the simple linear regression analysis we get the formula of male body height $=15.496+8.398 \mathrm{x}$ hand length, and the formula of female body height $=85.401+4.318 \mathrm{x}$ hand length, and in total body heigth $=42.621+6.897$ $\mathrm{x}$ hand length. Conclusion: There is a same direction and positive relationship between body height and hand length in the medical student of Sam Ratulangi University class of 2013.

Keywords: identification, hand length, body height.
\end{abstract}

\begin{abstract}
Abstrak: Identifikasi sangatlah penting pada korban yang telah meninggal, karena identifikasi dilakukan untuk mengetahui kepastian identitas seseorang. Tinggi badan dapat ditentukan menggunakan ukuran tulang-tulang panjang, diantaranya tulang-tulang metakarpal dan tulangtulang falang. Tujuan penelitian ini adalah untuk mengetahui hubungan antara tinggi badan dan panjang tangan pada mahasiswa Fakultas Kedokteraan Unsrat Angkatan 2013. Penelitian ini merupakan penelitian deskriptif analitik dengan rancangan cross-sectional, dengan sampel sejumlah 72 mahasiswa yang terdiri dari 36 mahasiswa laki-laki dan 36 mahasiswa perempuan. Sampel di pilih dengan menggunakan cara simple random sampling dan di analisis dengan analisis korelasi Pearson serta analisis regresi linier sederhana. Didapatkan hubungan yang kuat antara tinggi badan dengan panjang tangan dengan koefisien korelasi ( $\mathrm{r}$ ) pada keseluruhan subjek sebesar 0,855 , sedangkan pada laki-laki 0,753 dan pada perempuan 0,603 . Dari hasil analisis regresi linier sederhana di dapatkan rumus tinggi badan laki-laki $=$ $15,496+8,398 \times$ panjang tangan, tinggi badan perempuan $=85,401+4,318 \times$ panjang tangan, dan secara keseluruhan tinggi badan $=42,621+6,897$ x panjang tangan. Simpulan: Terdapat hubungan searah atau positif antara tinggi badan dengan panjang tangan pada mahasiswa Fakultas Kedokteran Universitas Sam Ratulangi angkatan 2013.
\end{abstract}

Kata kunci: identifikasi, panjang tangan, tinggi badan. 
Setiap manusia memiliki tubuh yang berbeda-beda, ada yang berbadan kecil dan ada juga yang berbadan besar, serta memiliki perbedaan antara panjang bagian tubuh yang satu dengan bagian tubuh yang lain. Berdasarkan pada anggapan bahwa pada saat manusia berdiri tegak dengan ekstremitas superior berada di samping tubuh, dan wajah serta telapak tangan menghadap ke depan adalah posisi anatomi. ${ }^{1}$

Anatomi manusia mengalami perkembangan bersama-sama dengan cabang ilmu kedokteran lainnya yang akhirnya menimbulkan ilmu terapan, salah satunya adalah antropologi ragawi. Dengan menggunakan teknik antropologi ragawi dapat diperkirakan umur, jenis kelamin, ukuran bagian-bagian badan manusia, dan jenis ras berdasarkan kerangka seseorang. Selain itu teknik antropologi ragawi ini dapat digunakan dalam proses identifikasi yang merupakan bidang telaah kedokteran forensik. ${ }^{2}$

Dalam bidang kedokteran forensik peranan pemeriksaan identifikasi sangatlah penting pada korban yang telah meninggal, karena setelah dilakukan identifikasi terhadap jenazah untuk kepastian identitas, barulah kemudian pemeriksaan dapat dilanjutkan pada tingkat berikutnya. Pada kasus mutilasi tak jarang pihak kepolisian hanya menyerahkan kepala saja, sebagian tangan atau kaki yang terpotong-potong atau kadang kala tinggal tulang belulang saja. ${ }^{3,4}$

Tinggi badan adalah ukuran seseorang pada saat masih hidup, sedangkan panjang badan adalah ukuran pada suatu jenazah atau pasien yang sedang berbaring. Panjang badan adalah salah satu hal penting untuk identifikasi. Maka untuk proses identifikasi tersebut, memperkirakan tinggi badan seseorang pada saat masih hidup dilakukan dengan mengukur panjang badan jenazah setelah meninggal. $^{4}$

Mengukur panjang jenazah ketika masih utuh bukanlah merupakan suatu pekerjaan yang sulit, namun kesulitan akan muncul bila jenazah mengalami kerusakan yang sangat hebat atau tidak lagi utuh. Jika di TKP (Tempat Kejadian Perkara) yang ditemukan hanya satu potongan tubuh yaitu potongan tangan, dengan mengetahui formula hubungan antara tinggi badan seseorang dengan panjang tangan dapat diperkirakan tinggi badan berdasarkan ukuran tangan. ${ }^{5}$

Beberapa penelitian tentang perkiraan tinggi badan berdasarkan panjang tangan mendapat hasil yang bermakna. Jasuja $(2004)^{6}$, Jitendra dkk $(2014)^{7}$, Pawar \& Dadhich $(2012)^{8}$, Ibegbu dkk (2013) ${ }^{9}$, Ilayperuma (2009) ${ }^{10}$, Laila dkk (2009) ${ }^{11}$, Numan (2013) ${ }^{12}$, Agrawal dkk (2013) ${ }^{13}$, Chikhalkar dkk (2009) ${ }^{14}$ melakukan penelitian yang membuktikan bahwa ada hubungan yang bermakna antara panjang tangan dan tinggi badan dengan formula yang tidak persis sama.

Adapun tujuan dari penelitian ini yaitu untuk mengetahui apakah terdapat hubungan antara tinggi badan dengan panjang tangan pada mahasiswa Fakutas Kedokteran Universitas Sam Ratulangi angkatan 2013.

\section{METODE PENELITIAN}

Penelitian ini merupakan jenis penelitian deskriptif analitik dengan desain penelitian cross-sectional yang dilaksanakan pada 12-14 November 2014. Populasi dalam penelitian ini adalah Mahasiswa Fakultas Kedokteran Unsrat angkatan 2013 yang berjumlah 250 orang. Sampel dipilih menggunakan cara simple random sampling yang telah memenuhi kriteria inklusi, dan disesuaikan dengan besar yang ditentukan berdasarkan rumus yaitu 72 orang yang terdiri dari 36 orang laki-laki dan 36 orang perempuan.

\section{HASIL PENELITIAN}

Jumlah sampel pada penelitian ini 72 orang dan data subjek penelitian disusun dalam tabel induk dengan kolom isian: nomor urut, nama, jenis kelamin, umur (dalam tahun), tinggi badan (dalam $\mathrm{cm}$ ), panjang tangan kanan (dalam $\mathrm{cm}$ ), panjang tangan kiri (dalam cm). 
Jurnal e-Biomedik (eBm), Volume 3, Nomor 1, Januari-April 2015

Tabel 1. Umur Subjek Penelitian

\begin{tabular}{lcll}
\hline $\begin{array}{l}\text { Jenis } \\
\text { Kelamin }\end{array}$ & $\mathrm{N}$ & $\begin{array}{l}\text { Umur } \\
\text { (tahun) }\end{array}$ & $\begin{array}{l}\text { Rata-rata } \\
\text { (tahun) }\end{array}$ \\
\hline Laki-laki & 36 & $18-20$ & 18,78 \\
Perempuan & 36 & $18-20$ & 18,67 \\
Keseluruhan & 72 & $18-20$ & 18,72 \\
\hline
\end{tabular}

Tabel 2. Tinggi Badan Subjek Penelitian

\begin{tabular}{llll}
\hline $\begin{array}{l}\text { Jenis } \\
\text { Kelamin }\end{array}$ & $\mathrm{N}$ & $\begin{array}{l}\text { Tinggi } \\
\text { Badan } \\
(\mathrm{cm})\end{array}$ & $\begin{array}{l}\text { Rata- } \\
\text { rata } \\
(\mathrm{cm})\end{array}$ \\
\hline Laki-laki & 36 & $161,0-184,7$ & 170,7 \\
Perempuan & 36 & $145,0-170,1$ & 158,0 \\
Keseluruhan & 72 & $145,0-184,7$ & 164,4 \\
\hline
\end{tabular}

Tabel 3. Panjang Tangan Kanan Subjek Penelitian

\begin{tabular}{llll}
\hline $\begin{array}{l}\text { Jenis } \\
\text { Kelamin }\end{array}$ & $\mathrm{N}$ & $\begin{array}{l}\text { Panjang } \\
\text { tangan } \\
\text { kanan }(\mathrm{cm})\end{array}$ & $\begin{array}{l}\text { Rata- } \\
\text { rata } \\
(\mathrm{cm})\end{array}$ \\
\hline Laki-laki & 36 & $18,0-19,9$ & 18,49 \\
Perempuan & 36 & $15,2-18,6$ & 16,82 \\
Keseluruhan & 72 & $15,2-19,9$ & 17,65 \\
\hline
\end{tabular}

Tabel 4. Panjang Tangan Kiri Subjek

Penelitian

\begin{tabular}{llll}
$\begin{array}{l}\text { Jenis } \\
\text { Kelamin }\end{array}$ & $\mathrm{N}$ & $\begin{array}{l}\text { Panjang } \\
\text { tangan } \\
\text { kiri }(\mathrm{cm})\end{array}$ & $\begin{array}{l}\text { Rata- } \\
\text { rata } \\
(\mathrm{cm})\end{array}$ \\
\hline Laki-laki & 36 & $18,0-19,9$ & 18,48 \\
Perempuan & 36 & $15,2-18,6$ & 16,83 \\
Keseluruhan & 72 & $15,2-19,9$ & 17,66 \\
\hline
\end{tabular}

Tabel 5. Panjang Tangan Kanan dan Kiri Subjek Penelitian

\begin{tabular}{llll}
\hline $\begin{array}{l}\text { Jenis } \\
\text { Kelamin }\end{array}$ & $\mathrm{N}$ & $\begin{array}{l}\text { Panjang } \\
\text { tangan } \\
(\mathrm{cm})\end{array}$ & $\begin{array}{l}\text { Rata- } \\
\text { rata } \\
(\mathrm{cm})\end{array}$ \\
\hline Laki-laki & 36 & $18,0-19,9$ & 18,49 \\
Perempuan & 36 & $15,2-18,6$ & 16,82 \\
Keseluruhan & 72 & $15,2-19,9$ & 17,66 \\
\hline
\end{tabular}

Tabel 6. Hubungan Tinggi Badan Dengan Panjang Tangan Kanan

\begin{tabular}{lcc}
\hline $\begin{array}{l}\text { Jenis } \\
\text { Kelamin }\end{array}$ & $\mathrm{N}$ & Korelasi Pearson (r) \\
\hline Laki-laki & 36 & 0,756 \\
Perempuan & 36 & 0,607 \\
Keseluruhan & 72 & 0,856 \\
\hline
\end{tabular}

Tabel 7. Hubungan Tinggi Badan Dengan Panjang Tangan Kiri

\begin{tabular}{lcc}
\hline $\begin{array}{l}\text { Jenis } \\
\text { Kelamin }\end{array}$ & N & Korelasi Pearson (r) \\
\hline Laki-laki & 36 & 0,747 \\
Perempuan & 36 & 0,599 \\
Keseluruhan & 72 & 0,854 \\
\hline
\end{tabular}

Tabel 8. Hubungan Tinggi Badan Dengan Panjang Tangan Kanan dan Kiri

\begin{tabular}{lcc}
\hline Jenis Kelamin & N & $\begin{array}{c}\text { Korelasi Pearson } \\
(\mathrm{r})\end{array}$ \\
\hline Laki-laki & 36 & 0,753 \\
Perempuan & 36 & 0,603 \\
Keseluruhan & 72 & 0,855 \\
\hline
\end{tabular}

Pada subjek penelitian laki-laki

a. Analisis regresi antara tinggi badan dengan panjang tangan kanan

Tinggi badan laki-laki $=11,622+8,607$ x panjang tangan kanan

b. Analisis regresi antara tinggi badan dengan panjang tangan kiri

Tinggi badan laki-laki $=20,150+8,147$ $\mathrm{x}$ panjang tangan kiri

c. Analisis regresi antara tinggi badan dengan panjang tangan

Tinggi badan laki-laki $=15,496+8,398$ $\mathrm{x}$ panjang tangan

Pada subjek penelitian perempuan

a. Analisis regresi antara tinggi badan dengan panjang tangan kanan

Tinggi badan perempuan $=85,340+$ 4,323 x panjang tangan kanan

b. Analisis regresi antara tinggi badan dengan panjang tangan kiri

Tinggi badan perempuan $=85,648+$ 4,301 x panjang tangan kiri

c. Analisis regresi antara tinggi badan dengan panjang tangan

Tinggi badan perempuan $=85,401+$ 4,318 x panjang tangan

Pada keseluruhan data yang diperoleh

a. Analisis regresi antara tinggi badan dengan panjang tangan kanan

Tinggi badan $=42,765+6,890 \mathrm{x}$ panjang tangan kanan

b. Analisis regresi antara tinggi badan dengan panjang tangan kiri 
Tinggi badan $=42,672+6,893 \mathrm{x}$ panjang tangan kiri

c. Analisis regresi antara tinggi badan dengan panjang tangan

Tinggi badan $=42,621+6,897 \mathrm{x}$ panjang tangan

\section{BAHASAN}

Pada penelitian ini yang menjadi sampel penelitian adalah mahasiswa Fakultas Kedokteran Universitas Sam Ratulangi angkatan 2013 yang berusia $\geq 18$ tahun dengan pertimbangan bahwa pertumbuhan tulang pada umumnya telah terhenti pada usia sekitar 18-20 tahun yang berarti pertambahan panjang badan pada usia 18-20 tahun relatif tidak bermakna. Subjek penelitian berjumlah 72 orang dengan jumlah subjek penelitian perempuan dan laki-laki masing-masing 36 orang serta tidak pernah mengalami patah tulang tangan, maupun punggung yang mungkin dapat mempengaruhi ukuran tinggi badan dan panjang tangan.

Tabel 1 diperoleh bahwa secara keseluruhan subjek penelitian berumur antara 18-20 tahun dengan rata-rata 18,72 \pm 0,633 tahun. Untuk subjek penelitian lakilaki pada penelitian ini berumur 18-20 tahun dengan rata-rata 18,78 $\pm 0,637$ tahun dan subjek penelitian perempuan berumur 18-20 tahun dengan rata-rata 18,67 $\pm 0,632$ tahun.

Tabel 2 dapat dilihat bahwa secara keseluruhan tinggi badan subjek penelitian adalah 145,0-184,7 cm dengan rata-rata $164,4 \pm 8,57 \mathrm{~cm}$. Tinggi badan pada subjek penelitian laki-laki adalah 161,0-184,7 cm dengan rata-rata $170,7 \pm 5,99 \mathrm{~cm}$ dan subjek penelitian perempuan adalah 145,0$170,1 \mathrm{~cm}$ dengan rata-rata $158,0 \pm 5,47 \mathrm{~cm}$.

Jadi terdapat perbedaan $12,7 \mathrm{~cm}$ antara tinggi badan subjek penelitian laki-laki dan perempuan.

Tabel 3 dapat dilihat bahwa terdapat perbedaan antara panjang tangan kanan subjek penelitian laki-laki dengan panjang tangan kanan subjek penelitian perempuan. Dimana panjang tangan kanan subjek penelitian laki-laki berkisar antara 18,0-
19,9 $\mathrm{cm}$ dengan rata-rata $18,49 \pm 0,52 \mathrm{~cm}$, sedangkan panjang tangan kanan subjek penelitian perempuan berkisar antara 15,2$18,6 \mathrm{~cm}$ dengan rata-rata $16,82 \pm 0,76 \mathrm{~cm}$. Dengan demikian terdapat perbedaan 1,67 cm antara panjang tangan kanan subjek penelitian laki-laki dan perempuan.

Tabel 4 dapat dilihat bahwa terdapat perbedaan antara panjang tangan kiri subjek penelitian laki-laki dengan panjang tangan kiri subjek penelitian perempuan. Dimana panjang tangan kiri subjek penelitian laki-laki berkisar antara 18,0$19,9 \mathrm{~cm}$ dengan rata-rata $18,48 \pm 0,55 \mathrm{~cm}$, sedangkan panjang tangan kiri subjek penelitian perempuan berkisar antara 15,2$18,6 \mathrm{~cm}$ dengan rata-rata $16,83 \pm 0,76 \mathrm{~cm}$. Dengan demikian terdapat perbedaan 1,65 cm antara panjang tangan kiri subjek penelitian laki-laki dan perempuan.

Tabel 5 secara keseluruhan panjang tangan kanan dan kiri subjek penelitian berkisar 15,2-19,9 cm dengan rata-rata $17,66 \pm 1,06 \mathrm{~cm}$. Untuk laki-laki panjang tangan keseluruhan antara 18,0-19,9 cm dengan rata-rata $18,49 \pm 0,53 \mathrm{~cm}$ dan pada perempuan panjang tangan keseluruhan antara 15,2-18,6 cm dengan rata-rata 16,82 $\pm 0,76 \mathrm{~cm}$.

Laki-laki memang cenderung lebih tinggi daripada perempuan. Hingga sekitar umur 10 tahun, anak perempuan dan lakilaki tumbuh dengan kecepatan yang cenderung sama. Akan tetapi pada umur 12 tahun, anak laki-laki sering mulai tumbuh lebih cepat dibanding anak perempuan sehingga kebanyakan remaja laki-laki lebih tinggi dari remaja perempuan. Hingga dewasa, laki-laki cenderung lebih tinggi dibandingkan perempuan, dan mempunyai tungkai yang lebih panjang dibandingkan perempuan. $^{1}$

Hasil penelitian tinggi badan subjek penelitian pada tabel 2 jika dihubungkan dengan panjang tangan subjek penelitian pada tabel 3, 4, dan 5 didapatkan tinggi badan berbanding lurus dengan panjang tangan. Artinya semakin besar ukuran panjang tangan maka semakin besar pula ukuran tinggi badan. 
Dari semua data yang terkumpul dilakukan analisis regresi antara tinggi badan dengan panjang tangan, baik tangan kanan, maupun tangan kiri, pada laki-laki dan perempuan serta keseluruhan subjek penelitian, dengan menggunakan rumus analisis regresi linear sederhana:

$$
\mathrm{Y}=\mathrm{a}+\mathrm{bX}
$$

$\mathrm{Y}=$ variabel terikat, dalam hal ini tinggi badan

$\mathrm{a}=$ nilai konstanta

$\mathrm{b}=$ koefisien regresi variabel bebas

$\mathrm{X}=$ variabel bebas, dalam hal ini panjang tangan

Untuk keseluruhan subjek penelitian baik panjang tangan kanan maupun panjang tangan kiri nilai koefisian korelasi (r) yaitu 0,855. Pada subjek penelitian laki-laki diperoleh nilai koefisien korelasi (r) yaitu 0,753. Pada subjek penelitian perempuan diperoleh nilai koefisien korelasi (r) yaitu 0,603. Dari hasil analisis diperoleh suatu korelasi yang kuat antara tinggi badan dengan panjang tangan.

Melalui analisis regresi didapatkan rumus persamaan untuk memperkirakan tinggi badan menggunakan panjang tangan.

a. Untuk subjek laki-laki didapatkan persamaan

Tinggi badan $=15,469+8,398 \mathrm{x}$ panjang tangan

b. Untuk subjek perempuan didapatkan persamaan

Tinggi badan $=85,401+4,318 \mathrm{x}$ panjang tangan

c. Untuk keseluruhan subjek penelitian didapatkan persamaan

Tinggi badan $=42,621+6,897 \mathrm{x}$ panjang tangan

Selain itu melalui analisis regresi didapatkan nilai koefisien determinasi yang dapat dilihat dari nilai R Square yaitu 0,567 pada laki-laki, yang berarti persamaan garis regresi yang diperoleh dapat menerangkan $56,7 \%$ variasi panjang rata-rata kedua tangan. Pada perempuan didapatkan nilai koefisien determinasi yang dapat dilihat dari nilai R Square yaitu 0,364 yang artinya persamaan garis regresi yang diperoleh dapat menerangkan 36,4\% variasi panjang rata-rata kedua tangan. Secara keseluruhan di dapatkan nilai R Square sebesar 0,732 yang berarti persamaan garis regresi dapat menerangkan $73,2 \%$ variasi panjang tangan.

Persamaan diatas, dapat dikatakan pada subjek laki-laki tinggi badan akan bertambah sebesar 8,398 cm bila panjang tangan rata-rata bertambah $1 \mathrm{~cm}$. Pada subjek penelitian perempuan tinggi badan akan bertambah 4,318 cm bila panjang tangan rata-rata bertambah $1 \mathrm{~cm}$. Dan secara keseluruhan, tinggi badan akan bertambah 6,897 $\mathrm{cm}$ bila panjang tangan rata-rata bertambah $1 \mathrm{~cm}$.

Hasil penelitian ini dengan nilai korelasi (r) laki-laki sebesar 0,753, nilai korelasi (r) perempuan sebesar 0,603,dan keseluruhan laki-laki dan perempuan dengan nilai korelasi (r) sebesar 0,855, memiliki nilai korelasi yang hampir sama dengan penelitian sejenis yang sebelumnya dilakukan oleh Ibegbu dkk (2013) ${ }^{9}$ dan pada Numan dkk (2013) ${ }^{12}$. Namun pada penelitian yang dilakukan oleh Ibegbu dkk (2013) pada penduduk Nigeria khususnya anak sekolah, nilai korelasi sedikit lebih besar karena subjek penelitian umurnya diantara 1-5 tahun, yang mana pertumbuhan tulang pada umur ini tulang masih mengalami pertumbuhan yang bervariasi, sedangkan pada penelitian ini dilakukan pada subjek penelitian umur antara 18-20 tahun karena sesuai dengan proses osifikasi tulang yang lambat dan baru selesai pada usia 18-20 jadi pada umur ini pertumbuhan tulang sudah terhenti. ${ }^{15}$

Pada penerapannya, rumus ini bisa digunakan untuk memperkirakan tinggi badan seseorang berdasarkan panjang tangannya dan dapat juga digunakan dalam pelengkap metode penentuan tinggi badan lainnya. Jadi secara keseluruhan sesuai dengan analisa data yang dilakukan maka pada penelitian ini terdapat hubungan yang bermakna antara tinggi badan dengan panjang tangan. 


\section{SIMPULAN}

Terdapat hubungan searah atau positif yang kuat antara tinggi badan dengan panjang tangan kanan dan kiri pada mahasiswa Fakultas Kedokteran Universitas Sam Ratulangi angkatan 2013.

\section{SARAN}

Kiranya dapat dilakukan penelitian seperti ini untuk perbandingan serta dengan sampel yang lebih besar dan perlu dilakukan ulasan, kajian dan penelitian lanjut misalnya berdasarkan ras atau suku bangsa yang ada di Indonesia yang tidak dilakukan pada penelitian ini, agar dapat mengetahui variasi tinggi badan berdasarkan ras atau suku bangsa serta perlu dilakukan penelitian pada sampel dibawah 18 tahun.

\section{DAFTAR PUSTAKA}

1. Snell RS. Anatomi Klinik Untuk Mahasiswa Kedokteran. Edisi 6. Jakarta: EGC. 2006; hal. 2, 31-35, 593595.

2. Suriyanto RA, Koeshardjono. Studi Variasi Indeks Acromiocristalis. Antropologi Indonesia 60. Universitas Gadjah Mada. 1999; hal. 86.

3. Sampurna B, Samsu Z, Siswajaya TD. Peranan Ilmu Forensik Dalam Penegakkan Hukum. Jakarta. 2008: 177-181.

4. Idries AM, Tjiptomartono AL. Penerapan Ilmu Kedokteran Forensik Dalam Proses Penyidikan. Jakarta. 2008: 177190.

5. Amir A. Identifikasi. Dalam: Ilmu Kedokteran Forensik. Edisi 2. Bagian Ilmu Kedokteran Forensik FK-USU. Medan. 2005: 178-203.

6. Jasuja OP. Estimation of Stature From Hand And Falangs Length. Journal of India Academy of Forensic Medicine. 2004; 26(3): 100-106.
7. Jitendra PP, Bhatat GP, Ritesh KS. Estimation of Stature From Hand Length In Gujarat Region. NHL Journal of Medical Sciences. 2014; 3(1): 41-44.

8. Pawar PK, Dadhich A. Study Of Correlation Between Human Height And Hand Length In Residents Of Mumbai. Int J Biol Med Res. 2012; 3(3): 2072-75.

9. Ibegbu AO. Association Of Hand Length With Height In Nigerian School Children. Journal of Biology And Life Science. 2013; 4(2): 83-94.

10.Ilayperuma I, Nanayakara G, Palahepitaya N. Prediction Of Personal Stature Based on The Hand Length. Galle Medical Journal. 2009; 14(1): 15-18.

11.Laila SZH, Ferdousi R, Nurrunobi ABM, Shafiqul ATM, Holy SZH, Yesmin F. Anthropometric Measurement of The Hand Length And Their Correlation With The Measure of Bengali Adult Muslim Females. Bangladesh Journal Anatomy. 2009; 7(1): 10-13.

12.Numan AI, Idris MO, Zirahei JV, Amaza DS, Dalori MB. Prediction of Stature From Hand Anthropometry: A Comparative Study In The Three Major Ethnic Groups In Nigeria. British Journal of Medicine and Medical Research. 2013; 3(4): 1062-73.

13.Agrawal J, Raichandani L, Kataria SK, Raichandani S. Estimation of The Stature From Hand Length And Length Falangs. Journal of Evolution Of Medical And Dental Sciences. 2013; 50(2):9651-56.

14.Chikhalkar BG, Mangaonkar AA, Nanandkar SD, Peddawad RG. Estimation of Stature from Measurement of Long Bones, Hand And Foot Dimensions. Journal Indian Academy Forensic Medicine. 2009; 32(4): 329-31.

15.Ganong WF. Buku Ajar Fisiologi Kedokteran. Edisi 17. Jakarta: EGC. 2001; p. 399-400. 